\title{
Thiobacter subterraneus gen. nov., sp. nov., an obligately chemolithoautotrophic, thermophilic, sulfur-oxidizing bacterium from a subsurface hot aquifer
}

\author{
Hisako Hirayama, ${ }^{1}$ Ken Takai, ${ }^{1}$ Fumio Inagaki, ${ }^{1}$ Kenneth $H$. Nealson ${ }^{1,2}$ \\ and Koki Horikoshi ${ }^{1}$
}

Correspondence

Hisako Hirayama

hirayamah@jamstec.go.jp

\author{
${ }^{1}$ Subground Animalcule Retrieval (SUGAR) Project, Japan Agency for Marine-Earth Science \\ and Technology (JAMSTEC), 2-15 Natsushima-cho, Yokosuka 237-0061, Japan \\ ${ }^{2}$ Department of Earth Sciences, University of Southern California, 3651 Trousdale Parkway, \\ Los Angeles, CA 90089-0740, USA
}

\begin{abstract}
A novel, thermophilic, obligately chemolithoautotrophic, sulfur/thiosulfate-oxidizing bacterium was isolated from subsurface geothermal aquifer water (temperature approximately $70^{\circ} \mathrm{C}$ ) in the Hishikari gold mine, Japan. Cells of the isolate, designated strain $\mathrm{C}^{5} 5^{\top}$, were motile, straight rods with a single polar flagellum. Growth was observed at temperatures between 35 and $62{ }^{\circ} \mathrm{C}$ (optimum $50-55^{\circ} \mathrm{C} ; 60$ min doubling time) and $\mathrm{pH}$ between $5 \cdot 2$ and $7 \cdot 7$ (optimum $\mathrm{pH} 6 \cdot 5-7 \cdot 0$ ). High growth rate of strain $\mathrm{C}_{5} 5^{\top}$ was observed on either thiosulfate or elemental sulfur as a sole energy source, with molecular oxygen as the only electron acceptor. None of the organic compounds tested supported or stimulated growth of strain $\mathrm{C}_{5} 5^{\top}$. The $\mathrm{G}+\mathrm{C}$ content of the genomic DNA was 66.9 mol\%. Phylogenetic analysis based on 16S rRNA gene sequences indicated that strain $\mathrm{C}_{5}{ }^{\top}$ was affiliated to the $\beta$-Proteobacteria, but was distantly related to recognized genera. On the basis of its physiological and molecular properties, strain $\mathrm{C}_{55}{ }^{\top}$ $\left(=\mathrm{JCM} 12421^{\top}=\mathrm{DSM} 16629^{\top}=\right.$ ATCC BAA- $\left.941^{\top}\right)$ is proposed as the type strain of Thiobacter subterraneus gen. nov., sp. nov.
\end{abstract}

During the last decade, studies using culture-dependent isolation techniques or culture-independent molecular analytical methods have suggested that thermophilic, chemolithotrophic, hydrogen- and/or sulfur-oxidizing micro-organisms within the order Aquificales and $\beta$ Proteobacteria are prevalent in terrestrial hot springs at high temperatures with neutral to alkaline $\mathrm{pH}$ (Huber et al., 1998; Hugenholtz et al., 1998; Reysenbach et al., 1994; Stöhr et al., 2001; Takai et al., 2001, 2002; Yamamoto et al., 1998). Previous culture-independent analyses of microbial communities in subsurface geothermal aquifer waters $\left(70-73^{\circ} \mathrm{C}\right)$ in a Japanese gold mine identified two predominant phylotypes, pHAuB-D within the Aquificales and $\mathrm{pHAuB}-J$ within the $\beta$-Proteobacteria, representing novel phylogenetic affiliations distantly related to previously cultivated strains (Takai et al., 2002). Numerous cultivation experiments to identify these previously uncultivated phylotypes were conducted by focusing on thermophilic

The GenBank/EMBL/DDBJ accession number for the 16S rRNA gene sequence of strain $\mathrm{C} 55^{\top}$ is $\mathrm{AB} 180657$.

Micrographs of cell morphology and a diagram showing the effects of temperature, $\mathrm{pH}$ and $\mathrm{Na}^{+}$concentration on growth of $\mathrm{C}_{5} 5^{\top}$ are available as supplementary figures in IJSEM Online. chemolithotrophs capable of using inorganic substrates enriched in the aquifer, and they resulted in successful isolation of several potential novel thermophilic species and the description of a novel hydrogen- and sulfur-oxidizing bacterium, Sulfurihydrogenobium subterraneus (Takai et al., 2002, 2003; Inagaki et al., 2003). In this study, isolation and characterization of another novel thermophilic sulfur/ thiosulfate-oxidizing bacterium within the $\beta$-Proteobacteria are described. The 16S rRNA gene sequence of this bacterium was similar to those of the previously detected environmental clones pHAuB-J from the mine and OPB37 from sulfide-rich sediment in the Obsidian Pool $\left(75-95^{\circ} \mathrm{C}\right)$ in Yellowstone National Park, USA (Hugenholtz et al., 1998).

A number of thermophilic, hydrogen- and/or sulfuroxidizing members of the $\beta$-Proteobacteria have been described, including genera such as Hydrogenophilus (Hayashi et al., 1999; Stöhr et al., 2001), Thiomonas (Shooner et al., 1996), Thermothrix (Caldwell et al., 1976; Odintsova et al., 1996), Tepidimonas (Moreira et al., 2000) and Thiobacillus (Wood \& Kelly, 1988). These organisms have been isolated from terrestrial hot-spring environments or wastewater-treatment plants, and most of them are 
facultatively autotrophic or strictly heterotrophic organisms. Thermothrix azorensis is obligately chemolithoautotrophic, using reduced sulfur compounds as the energy source. The new isolate showing obligately chemolithoautotrophic growth by the oxidation of reduced sulfur compounds is phylogenetically and physiologically compared with members of the genera within the $\beta$-Proteobacteria.

\section{Sample collection, enrichment and purification}

A hot $\left(70 \cdot 4^{\circ} \mathrm{C}\right)$ subsurface aquifer water from AW-S hole in the main deposit of the Hishikari gold mine, Kagoshima Prefecture, Japan, was obtained at the dewatering station in the mine (Izawa et al., 1990; Takai et al., 2002). At the time of sampling, $1 \mathrm{ml}$ of the hot aquifer water was inoculated into $3 \mathrm{ml} \mathrm{TSmj} \mathrm{medium} \mathrm{(see} \mathrm{below)} \mathrm{under} \mathrm{a} \mathrm{gas} \mathrm{phase} \mathrm{of}$ $80 \% \mathrm{~N}_{2}, 15 \% \mathrm{CO}_{2}$ and $5 \% \mathrm{O}_{2}(200 \mathrm{kPa})$. After transportation of the inoculated medium to the laboratory without temperature control, cultivation was performed at $55^{\circ} \mathrm{C}$ in a dry oven. Growth of motile, straight rods was observed after 3 days of incubation. A pure culture was obtained by using the repeated dilution-to-extinction technique (Baross, 1995) at $55^{\circ} \mathrm{C}$ with the same medium as used for the enrichment. This culture was designated strain $\mathrm{C} 55^{\mathrm{T}}$. Its purity was confirmed routinely by microscopic examination and by repeated partial sequencing of the $16 \mathrm{~S}$ rRNA gene using several PCR primers.

\section{Culture medium and conditions}

Strain $\mathrm{C} 55^{\mathrm{T}}$ was routinely cultivated in TSmj medium. TSmj medium consists of $1 \mathrm{~g} \mathrm{Na}_{2} \mathrm{~S}_{2} \mathrm{O}_{3} \cdot 5 \mathrm{H}_{2} \mathrm{O}, 0.5 \mathrm{~g} \mathrm{NaHCO}_{3}$, $0.5 \mathrm{~g} \mathrm{NH}_{4} \mathrm{Cl}, 1 \mathrm{~g} \mathrm{Na}_{2} \mathrm{SiO}_{3} .9 \mathrm{H}_{2} \mathrm{O}$ and $10 \mathrm{ml}$ vitamin mixture (Balch et al., 1979) per litre of mj water (Takai et al., 2001). The mj water consists of (per litre of distilled, deionized water) $3.0 \mathrm{~g} \mathrm{NaCl}, 14 \mathrm{mg} \mathrm{K} \mathrm{HPO}_{4}, 80 \mathrm{mg} \mathrm{CaCl}, 0.34 \mathrm{~g}$ $\mathrm{MgSO}_{4} \cdot 7 \mathrm{H}_{2} \mathrm{O}, 0.42 \mathrm{~g} \mathrm{MgCl}_{2} \cdot 6 \mathrm{H}_{2} \mathrm{O}, 33 \mathrm{mg} \mathrm{KCl}, 0.05 \mathrm{mg}$ $\mathrm{NiCl}_{2} .6 \mathrm{H}_{2} \mathrm{O}, 0.05 \mathrm{mg} \mathrm{Na} \mathrm{SeO}_{3} .5 \mathrm{H}_{2} \mathrm{O}, 0.01 \mathrm{mg} \mathrm{Na} \mathrm{WO}_{4}$, $2 \mathrm{mg} \mathrm{Fe}\left(\mathrm{NH}_{4}\right)_{2}\left(\mathrm{SO}_{4}\right)_{2} \cdot 6 \mathrm{H}_{2} \mathrm{O}$ and $1 \mathrm{ml}$ trace mineral solution (Balch et al., 1979). To prepare TSmj medium, all chemical reagents other than vitamin solution and $\mathrm{NaHCO}_{3}$ were dissolved, and the $\mathrm{pH}$ of the medium was adjusted to around $7 \cdot 0$ with $\mathrm{HCl}$ before autoclaving. After autoclaving under an air atmosphere, a concentrated solution of vitamins and $\mathrm{NaHCO}_{3}$ was added to the medium. The concentrated $\mathrm{NaHCO}_{3}$ solution was separately sterilized by autoclaving and the vitamin solution was filter-sterilized. The medium, dispensed at $20 \%$ of the bottle (Schott Glaswerke) or tube (Iwaki Glass) volume, was then purged with $80 \% \mathrm{~N}_{2}$ and $20 \% \mathrm{CO}_{2}$. The bottle or tube was tightly sealed with a butyl rubber stopper and the headspace was then pressurized with a gas mixture $\left(80 \% \mathrm{~N}_{2}, 18 \% \mathrm{CO}_{2}\right.$ and $2 \% \mathrm{O}_{2}$ ) at $200 \mathrm{kPa}$ unless otherwise indicated.

\section{Morphology}

Cells were observed under a phase-contrast Olympus BX51 microscope with the SPOT RT Slider CCD camera system (Diagnostic Instruments). Transmission electron microscopy of negatively stained cells was carried out as described by Zillig et al. (1990). Cells grown in TSmj medium under microaerobic conditions ( $2 \%$ partial pressure of $\mathrm{O}_{2}$ ) at $55^{\circ} \mathrm{C}$ in the mid-exponential phase of growth were negatively stained with $2 \%(\mathrm{w} / \mathrm{v})$ uranyl acetate and observed under a JEOL JEM-1210 electron microscope at an accelerating voltage of $120 \mathrm{kV}$. Cells of strain $\mathrm{C}^{2} 5^{\mathrm{T}}$ were Gramnegative rods, about $1 \cdot 1-1 \cdot 9 \mu \mathrm{m}$ long and $0 \cdot 4-0 \cdot 5 \mu \mathrm{m}$ wide, and were motile with a polar flagellum (see Supplementary Figs $\mathrm{A}$ and $\mathrm{B}$ in IJSEM Online).

\section{Growth characteristics}

Growth of strain $\mathrm{C} 55^{\mathrm{T}}$ was measured by direct cell counting after staining with 4',6-diamidino-2-phenylindole using a phase-contrast Olympus BX51 microscope. Duplicate cultures were prepared in $100 \mathrm{ml}$ glass bottles each containing $20 \mathrm{ml}$ medium, with shaking (100 r.p.m.) in a temperature-controlled dry oven. In TSmj medium, strain $\mathrm{C} 55^{\mathrm{T}}$ grew at the temperature range of $35-62^{\circ} \mathrm{C}$, with optimal growth at $50-55^{\circ} \mathrm{C}$. No growth was observed below $30^{\circ} \mathrm{C}$ or above $65^{\circ} \mathrm{C}$ (see Supplementary Fig. C in IJSEM Online). The effect of $\mathrm{pH}$ on growth was tested at $55^{\circ} \mathrm{C}$. The $\mathrm{pH}$ of TSmj medium was readjusted with $\mathrm{HCl}$ or $\mathrm{NaOH}$ immediately before inoculation. The $\mathrm{pH}$ of the TSmj medium used for this experiment was found to be stable during cultivation up to a density of $2 \times 10^{6}$ cells $\mathrm{ml}^{-1}$, and therefore growth was monitored in cultures with a density below this value. Growth of strain $\mathrm{C} 55^{\mathrm{T}}$ occurred at $\mathrm{pH} 5 \cdot 2-7 \cdot 7$, with optimum growth at $\mathrm{pH} 6 \cdot 5-$ $7 \cdot 0$ (Supplementary Fig. D). No growth was observed at $\mathrm{pH} 5 \cdot 1$ or $8 \cdot 5$.

To determine the effect of mineral salt concentration on growth, variously diluted or concentrated $\mathrm{mj}$ waters containing constant amounts of $\mathrm{Na}_{2} \mathrm{~S}_{2} \mathrm{O}_{3} \cdot 5 \mathrm{H}_{2} \mathrm{O}, \mathrm{NaHCO}_{3}$, $\mathrm{NH}_{4} \mathrm{Cl}, \mathrm{Na}_{2} \mathrm{SiO}_{3} .9 \mathrm{H}_{2} \mathrm{O}$, vitamin mixture and trace mineral solution were tested. Growth of strain $\mathrm{C} 55^{\mathrm{T}}$ was determined with several $\mathrm{Na}^{+}$concentrations in the medium. Strain $\mathrm{C} 55^{\mathrm{T}}$ grew at $\left[\mathrm{Na}^{+}\right]$between 20 and $280 \mathrm{mM}$. Optimum growth was seen at $70 \mathrm{mM}\left[\mathrm{Na}^{+}\right], 55^{\circ} \mathrm{C}$ and $\mathrm{pH} 6 \cdot 5$, with a 60 min doubling time (Supplementary Fig. E).

The effect of oxygen concentration in the gas phase was tested with TSmj medium under a series of gas mixtures of $\mathrm{N}_{2} / \mathrm{CO}_{2} / \mathrm{O}_{2}$ of $80: 20: 0,80: 19 \cdot 5: 0 \cdot 5,80: 19: 1,80: 18: 2$, $80: 15: 5,75: 15: 10$ or $65: 15: 20$, at $200 \mathrm{kPa}$. Growth of strain $\mathrm{C}_{5} 5^{\mathrm{T}}$ was observed at $0 \cdot 5-10 \% \mathrm{O}_{2}$ with an increase in cell numbers from $3 \times 10^{8}$ to $2 \times 10^{9}$ cells ml $^{-1}$. The maximum increase in growth of strain $\mathrm{C} 55^{\mathrm{T}}$ was seen under

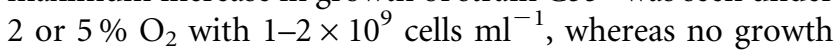
was observed either in the absence of $\mathrm{O}_{2}$ or under $20 \% \mathrm{O}_{2}$. These results indicated that strain $\mathrm{C}_{2} 5^{\mathrm{T}}$ is a microaerophilic organism.

Heterotrophic growth was examined in TSmj medium without $\mathrm{NaHCO}_{3}$ under a gas phase of $98 \% \mathrm{~N}_{2}$ and $2 \% \mathrm{O}_{2}$ $(200 \mathrm{kPa})$, containing potential organic carbon sources: $0 \cdot 1 \%(\mathrm{w} / \mathrm{v})$ each of yeast extract, peptone, tryptone and 
Casamino acids, $5 \mathrm{mM}$ each of formate, acetate, citrate, tartrate, fumarate, malate, succinate, lactate, oxalate and pyruvate, $0.02 \%(\mathrm{w} / \mathrm{v})$ each of glucose, galactose, sucrose, maltose and $0.01 \%$ methanol. Strain $\mathrm{C} 55^{\mathrm{T}}$ was not able to grow with any of the organic compounds tested as sole carbon sources. Furthermore, no stimulation of growth was observed with the addition of yeast extract or tryptone to TSmj medium containing thiosulfate, $\mathrm{NaHCO}_{3}$ and $\mathrm{CO}_{2}$ in a gas phase.

To determine potential electron donors other than thiosulfate for autotrophic growth, 1 or $5 \mathrm{mM}$ each of $\mathrm{Na}_{2} \mathrm{~S}$, cysteine hydrochloride, disulfate $\left(\mathrm{Na}_{2} \mathrm{~S}_{2} \mathrm{O}_{7}\right)$ or elemental sulfur $(3 \%$; w/v) was added to TSmj medium instead of thiosulfate as a sole electron donor with a gas phase of $80 \%$ $\mathrm{N}_{2}, 18 \% \mathrm{CO}_{2}$ and $2 \% \mathrm{O}_{2}(200 \mathrm{kPa})$. Molecular hydrogen was also examined in TSmj medium without thiosulfate with a gas phase of $80 \% \mathrm{H}_{2}, 18 \% \mathrm{CO}_{2}$ and $2 \% \mathrm{O}_{2}$ $(200 \mathrm{kPa})$. Elemental sulfur as an electron donor resulted in a similar maximum increase in cell numbers to that obtained with thiosulfate $\left(1 \times 10^{9}\right.$ cells ml $\left.{ }^{-1}\right)$, whereas $\mathrm{Na}_{2} \mathrm{~S}$ $(1 \mathrm{mM})$ produced lower cell numbers $\left(1-2 \times 10^{8}\right.$ cells $\mathrm{ml}^{-1}$ ) and other reduced sulfur compounds and hydrogen did not support growth of strain $\mathrm{C}_{5} 5^{\mathrm{T}}$ as the sole electron donor. $\mathrm{Na}_{2} \mathrm{~S}$ at $5 \mathrm{mM}$ seemed to be toxic to strain $\mathrm{C} 55^{\mathrm{T}}$. No electron acceptor tested $\left[\mathrm{NaNO}_{3}\right.$ (2 or $\left.10 \mathrm{mM}\right), \mathrm{NaNO}_{2}(1$ or $5 \mathrm{mM})$, ferric citrate $(20 \mathrm{mM})$, ferrihydrite $(20 \mathrm{mM})$, $\left.\mathrm{Na}_{2} \mathrm{SO}_{3}(5 \mathrm{mM}), \mathrm{Na}_{2} \mathrm{SO}_{4}(5 \mathrm{mM})\right]$ supported growth of strain $\mathrm{C}_{5} 5^{\mathrm{T}}$. These results indicate that strain $\mathrm{C} 55^{\mathrm{T}}$ is a chemolithoautotroph utilizing reduced sulfur compounds (thiosulfate, elemental sulfur or sulfide) as an energy source and molecular oxygen as the sole electron acceptor.

With regard to nitrogen sources for growth, strain $\mathrm{C} 55^{\mathrm{T}}$ utilized nitrate, ammonium and Casamino acids, but could not utilize $\mathrm{NaNO}_{2}$ or $\mathrm{N}_{2}$.

The time-course of oxidation of thiosulfate during growth of strain $\mathrm{C}^{2} 5^{\mathrm{T}}$ was monitored with TSmj medium at $\mathrm{pH} 6 \cdot 5$ under a gas phase of $80 \% \mathrm{~N}_{2}, 18 \% \mathrm{CO}_{2}$ and $2 \% \mathrm{O}_{2}$ $(200 \mathrm{kPa})$ at $55^{\circ} \mathrm{C}$ (Fig. 1). Concentrations of thiosulfate, sulfite and sulfate were analysed using the P/ACE MDQ capillary electrophoresis system (Beckman Coulter). Consumption of thiosulfate and production of sulfate were both observed during the growth of strain $\mathrm{C} 55^{\mathrm{T}}$. However, some inconsistency was observed in the stoichiometry of thiosulfate consumption and resulting sulfate production by strain $C 55^{\mathrm{T}}$. During the early growth phase $(0-3 \mathrm{~h})$, $1.4 \mathrm{mM}$ thiosulfate was consumed but only $0.2 \mathrm{mM}$ sulfate was produced ( $7 \%$ of the theoretical value) (Fig. 1). During the mid-exponential growth phase $(3-5 \mathrm{~h}), 0 \cdot 8 \mathrm{mM}$ thiosulfate was consumed and $1 \mathrm{mM}$ sulfate was produced ( $63 \%$ of the theoretical value). In contrast, in the late exponential growth phase $(5-7 \cdot 5 \mathrm{~h})$, consistency in stoichiometry was found, with $2 \cdot 1 \mathrm{mM}$ thiosulfate consumed and $4.3 \mathrm{mM}$ sulfate produced $(100 \%$ of the theoretical value). However, in the stationary growth phase $(7 \cdot 5-$ $16.5 \mathrm{~h}$ ), only $0 \cdot 1 \mathrm{mM}$ thiosulfate was consumed whereas $1 \cdot 2 \mathrm{mM}$ sulfate was produced $(600 \%$ of the theoretical

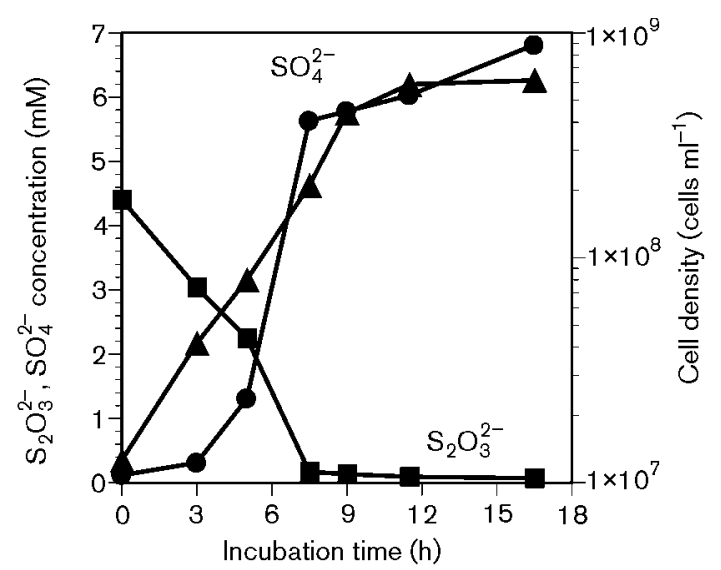

Fig. 1. Time-courses of oxidation of thiosulfate ( $\mathbf{\square})$, the production of sulfate $(\boldsymbol{O})$ and concomitant bacterial growth $(\boldsymbol{\Lambda})$ of strain $\mathrm{C} 55^{\top}$.

value). This result indicates possible accumulation of sulfur compounds in the cells of strain C55 ${ }^{\mathrm{T}}$, especially in the early stages of growth, because no obvious elemental sulfur precipitation was observed in the medium during growth. Accumulated sulfur compounds in the cells of strain $\mathrm{C} 55^{\mathrm{T}}$ were found during fatty acid analysis (see below). From the concentrated fatty acid sample extracted from whole cells of strain $\mathrm{C} 55^{\mathrm{T}}$, considerable amounts of sulfur compounds were precipitated. Further GC-MS analysis of the sample detected a cyclic polysulfur (8S) peak among the peaks of fatty acids. Therefore, strain $\mathrm{C} 55^{\mathrm{T}}$ seemed to transport thiosulfate into the cells and accumulate it as polysulfur, especially in the early stage of growth, for utilization as an energy source in the stationary phase. The production of sulfite was not observed during growth. The control medium (uninoculated) did not exhibit either thiosulfate oxidation or sulfate production. These results indicate that strain $\mathrm{C} 55^{\mathrm{T}}$ is a respiratory sulfur-oxidizer, producing sulfate as an end product.

Sensitivity to a variety of antibiotics in strain $\mathrm{C} 55^{\mathrm{T}}$ was examined with liquid TSmj medium containing each compound. Cell growth of strain $\mathrm{C} 55^{\mathrm{T}}$ was inhibited by chloramphenicol $\left(10 \mu \mathrm{g} \mathrm{ml}^{-1}\right)$, streptomycin $\left(10 \mu \mathrm{g} \mathrm{ml}^{-1}\right)$, kanamycin $\left(1 \mu \mathrm{g} \mathrm{ml}^{-1}\right)$, ampicillin $\left(1 \mu \mathrm{g} \mathrm{ml}^{-1}\right)$, rifampicin $\left(1 \mu \mathrm{g} \mathrm{ml}^{-1}\right)$ and vancomycin $\left(60 \mu \mathrm{g} \mathrm{ml}^{-1}\right)$.

\section{Fatty acid composition and $\mathrm{G}+\mathrm{C}$ content of genomic DNA}

The cellular fatty acid composition of cells grown in TSmj medium at $55^{\circ} \mathrm{C}$ in the late exponential growth phase was determined. Lyophilized cells $(100 \mathrm{mg})$ were placed in a Teflon-lined, screw-capped tube containing $3 \mathrm{ml}$ anhydrous methanolic $\mathrm{HCl}$ and heated at $100^{\circ} \mathrm{C}$ for $3 \mathrm{~h}$. Extraction and analysis of fatty acid methyl esters were done as described by Takai et al. (2003). The major cellular fatty acids of strain $\mathrm{C}_{5} 5^{\mathrm{T}}$ were $\mathrm{C}_{16: 0}(72 \cdot 8 \%), \mathrm{C}_{16: 1}(23 \cdot 1 \%)$, 
$\mathrm{C}_{18: 0}(2 \cdot 3 \%)$, iso- $\mathrm{C}_{18: 0}(1 \cdot 3 \%)$ and $\mathrm{C}_{18: 1}(0 \cdot 4 \%)$. The ratio of $n$ - $\mathrm{C}_{16}$ fatty acids $(95.9 \%$ of the total fatty acids) in strain $\mathrm{C} 55^{\mathrm{T}}$ was high in comparison with other thermophilic micro-organisms within the $\beta$-Proteobacteria, such as Hydrogenophilus hirschii (58\%; Stöhr et al., 2001), Tepidimonas ignava (49\%; Moreira et al., 2000) or Tepidiphilus margaritifer (43\%; Manaia et al., 2003). Genomic DNA of strain $\mathrm{C} 55^{\mathrm{T}}$ was prepared as described by Marmur \& Doty (1962). The DNA G +C content was determined by direct analysis of deoxyribonucleotides using HPLC (Tamaoka \& Komagata, 1984). The G + C content of the genomic DNA of strain $\mathrm{C}_{5} 5^{\mathrm{T}}$ was $66.9 \mathrm{~mol} \%$, a value similar to that of other thermophilic members of the $\beta$ Proteobacteria, including Hydrogenophilus thermoluteolus (63.5 mol\%; Hayashi et al., 1999), Tepidiphilus margaritifer (64.8 mol\%; Manaia et al., 2003), Thiobacillus aquaesulis (65.7 mol\%; Wood \& Kelly, 1988) and Tepidimonas ignava (69.7\%; Moreira et al., 2000) (Table 1).

\section{5 rRNA gene sequence and phylogenetic analysis}

The nearly complete sequence (1452 bp) of the 16S rRNA gene of strain $\mathrm{C}_{5} 5^{\mathrm{T}}$ was amplified by PCR and directly sequenced from both strands with a DNA sequencer model 3100 (Perkin Elmer/Applied Biosystems). Similarity of the $16 \mathrm{~S}$ rRNA gene sequence to the nucleotide sequence database of DDBJ was analysed using the gapped-BLAST and FASTA search algorithms. A phylogenetic tree was constructed with the sequences of strain $\mathrm{C} 55^{\mathrm{T}}$ and several micro-organisms using the neighbour-joining algorithm in CLUSTAL X version 1.81. Similarity analysis indicated that strain $\mathrm{C} 55^{\mathrm{T}}$ is related to members of the $\beta$-Proteobacteria, and comparative evolutionary distance analysis demonstrated that the isolate represents a separate lineage of descent within the $\beta$-Proteobacteria (Fig. 2). The highest similarity (98\%) was observed between the 16S rRNA gene sequences of strain $\mathrm{C} 55^{\mathrm{T}}$ and the environmental clone pHAuB-J previously detected from the same hot aquifer water (Takai et al., 2002). The sequence of strain $\mathrm{C} 55^{\mathrm{T}}$ was also similar to that of environmental clone OBP37 (95\%), which was detected from sulfide-rich sediment in the Obsidian Pool $\left(75-95^{\circ} \mathrm{C}\right)$ in Yellowstone National Park, USA (Hugenholtz et al., 1998). Other than these environmental clone sequences, strain $\mathrm{C} 55^{\mathrm{T}}$ was distantly related to members of other genera within the $\beta$-Proteobacteria, such as Azoarcus buckelii $\mathrm{U}_{120^{\mathrm{T}}}$ (92.9\%; Mechichi et al., 2002), Sterolibacterium denitrificans Chol- $1 S^{\mathrm{T}}(92 \cdot 1 \%$; Tarlera \& Denner, 2003), Thiobacillus aquaesulis ATCC $43788^{\mathrm{T}}$ (91.8\%; Wood \& Kelly, 1988), Tepidiphilus margaritifer $\mathrm{N} 2-214^{\mathrm{T}}(90 \cdot 8 \%$; Manaia et al., 2003), Tepidimonas ignava SPS- $1037^{\mathrm{T}}$ (90.6\%; Moreira et al., 2000), Hydrogenophilus thermoluteolus $\mathrm{HT}-\mathrm{1}^{\mathrm{T}}(89 \cdot 1 \%$; Hayashi et al., 1999) and Thiomonas thermosulfata ATCC $51520^{\mathrm{T}}$ (85.5\%; Shooner et al., 1996).

\section{Comparison with related genera}

In recent years, a number of workers using cultureindependent molecular analyses have reported the

Table 1. Comparison of properties among thermophilic members of the $\beta$-Proteobacteria

Strains: 1, Thiobacter subterraneus gen. nov., sp. nov. C55 ${ }^{\mathrm{T}}$; 2, Thiobacillus aquaesulis ATCC $43788^{\mathrm{T}}$ (data from Wood \& Kelly, 1988); 3, Tepidimonas ignava SPS-1037 ${ }^{\mathrm{T}}$ (Moreira et al., 2000); 4, Tepidiphilus margaritifer N2-214 ${ }^{\mathrm{T}}$ (Manaia et al., 2003); 5, Hydrogenophilus thermoluteolus $\mathrm{TH}-1^{\mathrm{T}}$ (Hayashi et al., 1999); 6, Thiomonas thermosulfata ATCC $51520^{\mathrm{T}}$ (Shooner et al., 1996). ND, Not described.

\begin{tabular}{|c|c|c|c|c|c|c|}
\hline Characteristic & 1 & 2 & 3 & 4 & 5 & 6 \\
\hline \multicolumn{7}{|l|}{ Temperature for growth $\left({ }^{\circ} \mathrm{C}\right)$ : } \\
\hline Range & $35-62$ & $30-55$ & $35-65$ & $25-61$ & $35-54$ & $34-65$ \\
\hline Optimum & $50-55$ & $40-50$ & $50-55$ & 50 & 52 & $50-53$ \\
\hline \multicolumn{7}{|l|}{$\mathrm{pH}$ for growth: } \\
\hline Range & $5 \cdot 2-7 \cdot 7$ & $7 \cdot 0-9 \cdot 0$ & $6 \cdot 5-9 \cdot 5$ & $6 \cdot 0-8 \cdot 0$ & ND & $4 \cdot 3-7 \cdot 8$ \\
\hline Optimum & $6 \cdot 5-7 \cdot 0$ & $7 \cdot 5-8 \cdot 0$ & $7 \cdot 5-8 \cdot 5$ & $\mathrm{ND}$ & 7 & $5 \cdot 2-5 \cdot 6$ \\
\hline \multicolumn{7}{|l|}{ Energy source: } \\
\hline Reduced sulfur compounds & + & + & + & - & ND & + \\
\hline $\mathrm{H}_{2}$ & - & ND & ND & $\begin{array}{l}\text { Hydrogenase- } \\
\text { positive }\end{array}$ & + & ND \\
\hline Organic substrates & - & + & + & + & + & + \\
\hline \multicolumn{7}{|l|}{ Carbon source: } \\
\hline $\mathrm{CO}_{2}$ & + & + & - & - & + & + \\
\hline Organic carbon & - & + & + & + & + & + \\
\hline Anaerobic growth & - & + & - & + & + & - \\
\hline $\mathrm{G}+\mathrm{C}$ content of genomic DNA $(\mathrm{mol} \%)$ & $66 \cdot 9$ & $65 \cdot 7$ & $69 \cdot 7$ & $64 \cdot 8$ & $63 \cdot 5$ & 61 \\
\hline Isolation site & $\begin{array}{l}\text { Subsurface } \\
\text { hot aquifer }\end{array}$ & $\begin{array}{c}\text { Hot } \\
\text { spring }\end{array}$ & $\begin{array}{c}\text { Hot } \\
\text { spring }\end{array}$ & $\begin{array}{l}\text { Wastewater- } \\
\text { treatment plant }\end{array}$ & $\begin{array}{c}\text { Hot } \\
\text { spring }\end{array}$ & $\begin{array}{l}\text { Wastewater- } \\
\text { treatment plant }\end{array}$ \\
\hline
\end{tabular}




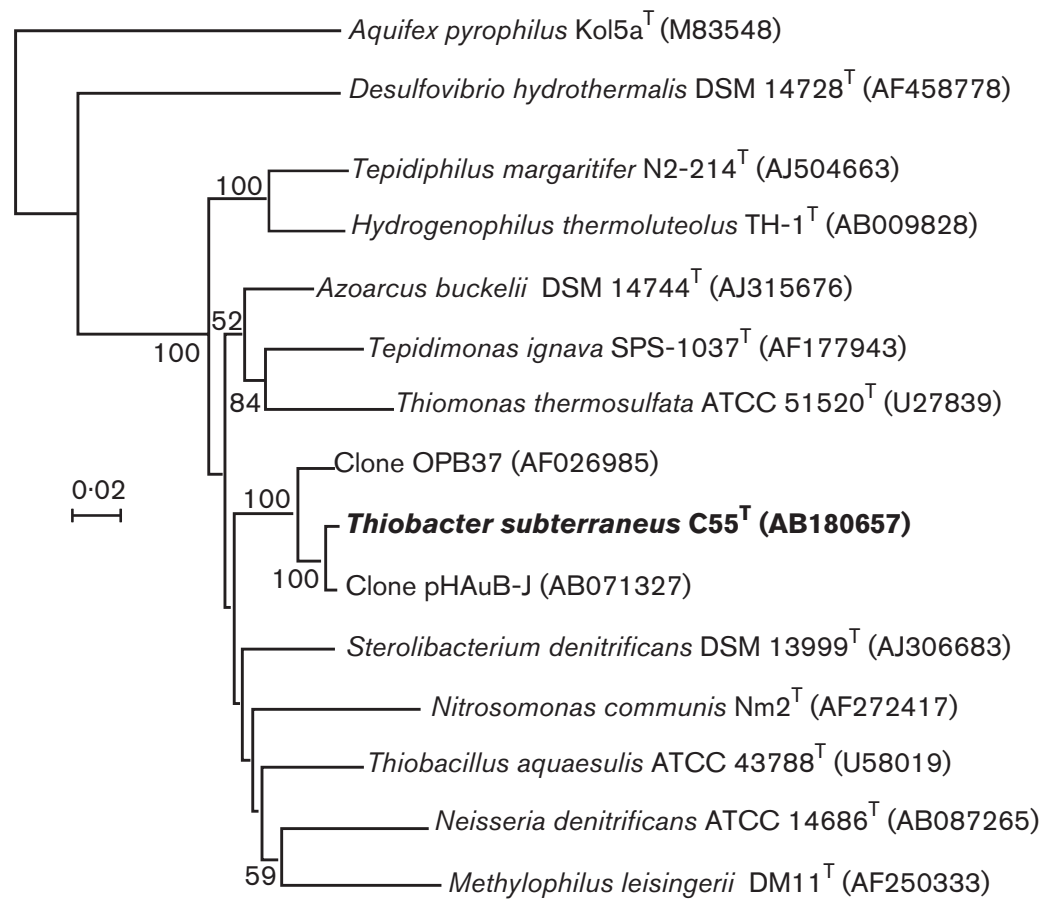

Fig. 2. Phylogenetic tree constructed on the basis of $16 \mathrm{~S}$ rRNA gene sequences showing the positions of the isolated strain $C 55^{\top}$ and representative members within the $\beta$-Proteobacteria, including environmental clone sequences. The tree was constructed by the neighbour-joining method on 904 homologous sequence positions. Numbers at nodes indicate bootstrap confidence values (100 replicates). Only values above $50 \%$ are shown. Bar, 2 substitutions per 100 nucleotides. dominance of $\beta$-Proteobacteria in hot springs and other high temperature environments (Hugenholtz et al., 1998; LaPara et al., 2000; Yamamoto et al., 1998). Yet relatively few thermophilic micro-organisms within the $\beta$-Proteobacteria have been isolated and described, and almost none of these has been an obligate chemolithoautotroph (Table 1). Thiobacillus aquaesulis ATCC $43788^{\mathrm{T}}$ and Thiomonas thermosulfata ATCC $51520^{\mathrm{T}}$ are facultatively chemolithoautotrophic sulfur-oxidizers, whereas Tepidimonas ignava SPS- $1037^{\mathrm{T}}$ is an obligate heterotroph with the ability to use reduced sulfur compounds as an energy source. Species of the genus Hydrogenophilus are facultative chemolithoautotrophs by the oxidation of $\mathrm{H}_{2}$, and a chemo-organoheterotrophic Tepidiphilus margaritifer strain $\mathrm{N} 2-214^{\mathrm{T}}$ is reported to show a positive hydrogenase activity. In comparison with these thermophilic species of $\beta$-Proteobacteria isolated from terrestrial hot-spring environments or wastewater-treatment plants, strain $\mathrm{C} 55^{\mathrm{T}}$ represents obligately chemolithoautotrophic growth by the oxidation of reduced sulfur compounds, and is the first thermophilic isolate from a subsurface geothermal environment within the $\beta$-Proteobacteria. On the basis of its physiological and molecular properties, we consider that strain $\mathrm{C} 55^{\mathrm{T}}$ represents a novel genus, Thiobacter gen. nov., with type species Thiobacter subterraneus sp. nov.

\section{Description of Thiobacter gen. nov.}

Thiobacter (Thi.o.bac'ter. Gr. neut. n. thion sulfur; N.L. masc. n. bacter a rod; N.L. masc. n. Thiobacter sulfur rod).

Cells are Gram-negative, motile and rod-shaped. Thermophilic aerobe. Growth occurs chemolithoautotrophically with reduced sulfur compounds as electron donors and with oxygen as an electron acceptor using $\mathrm{CO}_{2}$ as a carbon source. Phylogenetically affiliated to the $\beta$-Proteobacteria. The type species is Thiobacter subterraneus.

\section{Description of Thiobacter subterraneus sp. nov.}

Thiobacter subterraneus (sub.ter.ra'ne.us. L. masc. adj. subterraneus under the earth, indicating the source of isolation).

Cells are straight with a polar flagellum, $1 \cdot 1-1 \cdot 9 \mu \mathrm{m}$ long and $0 \cdot 4-0 \cdot 5 \mu \mathrm{m}$ wide. Microaerobic (up to $10 \% \mathrm{O}_{2}$ in a gas phase, optimum $2-5 \%)$. Temperature range for growth is $35-62{ }^{\circ} \mathrm{C}$ (optimum $50-55^{\circ} \mathrm{C}$ ). $\mathrm{pH}$ range for growth is $5 \cdot 2-7 \cdot 7$ (optimum $6 \cdot 5-7 \cdot 0$ ). $\mathrm{Na}^{+}$concentration range for growth is $20-280 \mathrm{mM}$ (optimum $70 \mathrm{mM}$ ). Chemolithoautotrophic growth occurs with elemental sulfur and reduced sulfur compounds, such as thiosulfate and sulfide, as electron donors and with molecular oxygen as the sole electron acceptor. Obligately autotrophic using $\mathrm{CO}_{2}$ as the sole carbon source. Nitrate and ammonium are used for the nitrogen source. The major cellular fatty acids are $\mathrm{C}_{16: 0}(72 \cdot 8 \%), \mathrm{C}_{16: 1}(23 \cdot 1 \%), \mathrm{C}_{18: 0}(2 \cdot 3 \%)$, iso- $\mathrm{C}_{18: 0}$ $(1 \cdot 3 \%)$ and $\mathrm{C}_{18: 1}(0 \cdot 4 \%)$. The DNA $\mathrm{G}+\mathrm{C}$ content is $66 \cdot 9 \pm 0 \cdot 2 \mathrm{~mol} \%$ (by HPLC).

The type strain, C55 $5^{\mathrm{T}}\left(=\mathrm{JCM} 12421^{\mathrm{T}}=\mathrm{DSM} 16629^{\mathrm{T}}=\right.$ ATCC BAA- $941^{\mathrm{T}}$ ), was isolated from subsurface hot aquifer water in the Hishikari gold mine, Kagoshima Prefecture, Japan.

\section{Acknowledgements}

We are grateful to Sumitomo Metal Mining Co. Ltd for its cooperation. We would like to thank Dr Katsuyuki Uematsu for assistance in preparing electron micrographs. 


\section{References}

Balch, W. E., Fox, G. E., Magrum, L. J., Woese, C. R. \& Wolfe, R. S. (1979). Methanogens: reevaluation of a unique biological group. Microbiol Rev 43, 260-296.

Baross, J. A. (1995). Isolation, growth and maintenance of hyperthermophiles. In Archaea: a Laboratory Manual, Thermophiles, pp. 15-23. Edited by F. T. Robb \& A. R. Place. Cold Spring Harbor, NY: Cold Spring Harbor Laboratory.

Caldwell, D. E., Caldwell, S. J. \& Laycock, J. P. (1976). Thermothrix thioparus gen. et sp. nov., a facultatively anaerobic facultative chemolithotroph living at neutral $\mathrm{pH}$ and high temperature. Can J Microbiol 22, 1509-1517.

Hayashi, N. R., Ishida, T., Yokota, A., Kodama, T. \& Igarashi, Y. (1999). Hydrogenophilus thermoluteolus gen. nov., sp. nov., a thermophilic, facultatively chemolithoautotrophic, hydrogen-oxidizing bacterium. Int J Syst Bacteriol 49, 783-786.

Huber, R., Eder, W., Heldwein, S., Wanner, G., Huber, H., Rachel, R. \& Stetter, K. O. (1998). Thermocrinis ruber gen. nov., sp. nov., a pink-filament-forming hyperthermophilic bacterium isolated from Yellowstone National Park. Appl Environ Microbiol 64, 3576-3583.

Hugenholtz, P., Pitulle, C., Hershberger, K. L. \& Pace, N. R. (1998). Novel division level bacterial diversity in a Yellowstone hot spring. J Bacteriol 180, 366-376.

Inagaki, F., Takai, K., Hirayama, H., Yamato, Y., Nealson, K. H. \& Horikoshi, K. (2003). Distribution and phylogenetic diversity of the subsurface microbial community in a Japanese epithermal gold mine. Extremophiles 7, 307-317.

Izawa, E., Urashima, Y., Ibaraki, K., Suzuki, R., Yokoyama, T., Kawasaki, K., Koga, A. \& Taguchi, S. (1990). The Hishikari gold deposit: high-grade epithermal veins in Quaternary volcanics of southern Kyushu, Japan. J Geochem Explor 36, 1-56.

LaPara, T. M., Nakatsu, C. H., Pantea, L. \& Alleman, J. E. (2000). Phylogenetic analysis of bacterial communities in mesophilic and thermophilic bioreactors treating pharmaceutical wastewater. Appl Environ Microbiol 66, 3951-3959.

Manaia, C. M., Nogales, B. \& Nunes, O. C. (2003). Tepidiphilus margaritifer gen. nov., sp. nov., isolated from a thermophilic aerobic digester. Int J Syst Evol Microbiol 53, 1405-1410.

Marmur, J. \& Doty, P. (1962). Determination of the base composition of deoxyribonucleic acid from its thermal denaturation temperature. J Mol Biol 5, 109-118.

Mechichi, T., Stackebrandt, E., Gad'on, N. \& Fuchs, G. (2002). Phylogenetic and metabolic diversity of bacteria degrading aromatic compounds under denitrifying conditions, and description of Thauera phenylacetica sp. nov., Thauera aminoaromatica sp. nov., and Azoarcus buckelii sp. nov. Arch Microbiol 178, 26-35.
Moreira, C., Rainey, F. A., Nobre, M. F., da Silva, M. T. \& da Costa M. S. (2000). Tepidimonas ignava gen. nov., sp. nov., a new chemolithoheterotrophic and slightly thermophilic member of the $\beta$-Proteobacteria. Int J Syst Evol Microbiol 50, 735-742.

Odintsova, E. V., Jannasch, H. W., Mamone, J. A. \& Langworthy, T. A. (1996). Thermothrix azorensis sp. nov., an obligately chemolithoautotrophic, sulfur-oxidizing, thermophilic bacterium. Int J Syst Bacteriol 46, 422-428.

Reysenbach, A.-L., Wickham, G. S. \& Pace, N. R. (1994). Phylogenetic analysis of the hyperthermophilic pink filament community in Octopus Spring, Yellowstone National Park. Appl Environ Microbiol 60, 2113-2119.

Shooner, F., Bousquet, J. \& Tyagi, R. D. (1996). Isolation, phenotypic characterization, and phylogenetic position of a novel, facultatively autotrophic, moderately thermophilic bacterium, Thiobacillus thermosulfatus sp. nov. Int J Syst Bacteriol 46, 409-415.

Stöhr, R., Waberski, A., Liesack, W., Völker, H., Wehmeyer, U. \& Thomm, M. (2001). Hydrogenophilus hirschii sp. nov., a novel thermophilic hydrogen-oxidizing $\beta$-proteobacterium isolated from Yellowstone National Park. Int J Syst Evol Microbiol 51, 481-488.

Takai, K., Komatsu, T. \& Horikoshi, K. (2001). Hydrogenobacter subterraneus sp. nov., an extremely thermophilic, heterotrophic bacterium unable to grow on hydrogen gas, from deep subsurface geothermal water. Int J Syst Evol Microbiol 51, 1425-1435.

Takai, K., Hirayama, H., Sakihama, Y., Inagaki, F., Yamato, Y. \& Horikoshi, K. (2002). Isolation and metabolic characteristics of previously uncultured members of the order Aquificales in a subsurface gold mine. Appl Environ Microbiol 68, 3046-3054.

Takai, K., Kobayashi, H., Nealson, K. H. \& Horikoshi, K. (2003). Sulfurihydrogenibium subterraneum gen. nov., sp. nov., from a subsurface hot aquifer. Int J Syst Evol Microbiol 53, 823-827.

Tamaoka, J. \& Komagata, K. (1984). Determination of DNA base composition by reversed-phase high-performance liquid chromatography. FEMS Microbiol Lett 25, 125-128.

Tarlera, S. \& Denner, E. B. M. (2003). Sterolibacterium denitrificans gen. nov., sp. nov., a novel cholesterol-oxidizing, denitrifying member of the $\beta$-Proteobacteria. Int J Syst Evol Microbiol 53, 1085-1091.

Wood, A. P. \& Kelly, D. P. (1988). Isolation and physiological characterisation of Thiobacillus aquaesulis sp. nov., a novel facultatively autotrophic moderate thermophile. Arch Microbiol 149, 339-343.

Yamamoto, H., Hiraishi, A., Kato, K., Chiura, H. X., Maki, Y. \& Shimizu, A. (1998). Phylogenetic evidence for the existence of novel thermophilic bacteria in hot spring sulfur-turf microbial mats in Japan. Appl Environ Microbiol 64, 1680-1687.

Zillig, W., Holz, I., Janekovic, D. \& 7 other authors (1990). Hyperthermus butylicus, a hyperthermophilic sulfur-reducing archaebacterium that ferments peptides. J Bacteriol 172, 3959-3965. 